NOTAS DE LEITURA 


\title{
MORTE QUE É VIDA
}

\author{
Luís Bueno*
}

Depois eu descobriria

que era licito

te chamar: flor!

Antiode (contra a poesia dita profunda)

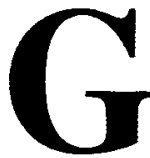

arante o bom senso que é sempre útil esperar algum tempo e nunca escrever sob o impacto imediato de um acontecimento forte. Contrariando esta regra, acho que vale a pena pensar um pouco sobre a poesia de João Cabral nos dias imediatamente posteriores ao da sua morte, numa tentativa - certamente apressada e talvez desajeitada - de inverter alguns hábitos de leitura que se converteram em valor de verdade pela força da repetição e pela aparente confiabilidade da fonte - o próprio escritor. A idéia de que o poeta é um engenheiro acabou sendo entendida, em primeiro lugar, como uma abdicação do eu e, em segundo lugar, como a redução do afazer poético a uma operação mais ou menos fria de formas. Essa visão, já com estatuto de senso comum, reapareceu nas reportagens que se fizeram em torno da morte e do enterro do poeta. $O$ final de $O$ engenheiro já indica o erro dessa visão:

* Universidade Federal do Paraná. 


\begin{abstract}
A água, o vento, a claridade
de um lado o rio, no alto as nuvens,

situavam na natureza o edifício

crescendo de suas forças simples. ${ }^{1}$
\end{abstract}

O edifício nasce na relação com a natureza - antítese do edifício - e se define nessa relação. Embora estranho, enquanto procedimento, em meio à natureza, forma-se a partir dos seus materiais ("a luz, o sol, o ar livre/ envolvem o sonho do engenheiro") e, depois de pronto, dialoga com ela. A confusão que se faz tem origem na identificação entre o confessional e o individual. Afastar a poesia do confessional não significa, nem por um átimo, apagar o eu. ${ }^{2}$ Falar de si mesmo não é a única forma de expressar um eu - e decerto não é a mais forte. Que outro adjetivo, além de "pessoal", pode ser aplicado à dicção poética de João Cabral com plena justiça? E de onde vem uma diç̧ão pessoal senão de um eu?

Dessa confusão nasce outra, muito comum, entre a poesia que é elaborada a partir de uma emoção e aquela que comove. A poesia intencionalmente emotiva pode comover, mas não é a única que o faz. Antes de João Cabral, um poeta como Manuel Bandeira já demonstrara isso para quem quisesse ver, num texto citadíssimo como $O$ cacto ou neste não menos conhecido Poema tirado de uma noticia de jornal.

João Gostoso era carregador de feira livre e morava no morro [da Babilônia num barracão sem número. Uma noite ele chegou no bar Vinte de Novembro

Bebeu

Cantou

Dançou

Depois se atirou na Lagoa Rodrigo de Freitas e morreu afogado. ${ }^{3}$ 1994, p. 70.

1 MELO NETO, João Cabral de. In: Obras completas. Rio de Janeiro: Nova Aguilar,

2 A frase de Le Corbusier que serve de epígrafe a $O$ engenheiro, aliás, já aponta para isso: “...machina à émouvoir...”. Ver MELO NETO, p. 66.

3 BANDEIRA, Manuel. Poesia completa e prosa. Rio de Janeiro: Nova Aguilar, 1990. p. 214. 
Não há eu nenhum a se exprimir diretamente aí, o que não significa ausência do eu e, muito menos, seqüestro da emoção. Escondido atrás do poema, lendo o fato e o refazendo num corte poético específico, está, gigante, esse eu. Não é de outra natureza o eu que se deve procurar na poesia de João Cabral. Trata-se de um eu que olha o mundo e o recorta com aquela faca só lâmina, é certo, mas com um olho vivo e vivíssimo que conduz a mão que sustém essa faca. Estas notas, que tratarão mais de um tema cabralino do que de processos, são feitas por alguém que não consegue ler o poeta pernambucano sem se comover.

A morte, neste caso, não precisa representar dificuldade alguma, já que é esse o tema nuclear que pode muito bem indicar um movimento geral da obra. Porque em João Cabral, numa espécie de espírito barroco ao revés, morte e vida constituem as tais duas faces da moeda da vida humana, mas o foco central de onde tudo parte e, ao final, para onde tudo volta, é a vida mesma, e não a morte. A vida não é sonho diante da outra vida que a morte enseja. A morte é que fecha a vida e dá a ela uma espécie de sentido final, como se morrer não fosse mais que reafirmar a vida.

Antes de chegar à poesia, entretanto, é interessante passar por Da função moderna da poesia, um texto em prosa de 1954 em que João Cabral coloca "o problema principal da poesia de hoje - que é o de sua própria sobrevivência". 4 Ou seja, uma reflexão sobre a poesia de seu tempo que parte dos limites entre morte e vida. Como se sabe, essa não é uma questão colocada apenas por João Cabral: a morte da poesia é mesmo um dos pilares básicos sobre os quais se assentam as tentativas dos poetas concretos de São Paulo para instituir uma nova poesia, feita de novos materiais, e serviu de mote para a brincadeira de José Paulo Paes, ao dizer que a poesia estava morta, mas ele jurava que não era ele. De qualquer forma, João Cabral vai propor dois remédios para o problema da sobrevivência da poesia. O primeiro deles é o da sua inserção nos modernos meios de difusão. Segundo ele, os poetas modernos não conseguiram escrever poemas que levassem em conta as limitações e explorassem as potencialidades do rádio, por exemplo. O segundo é que eles também desprezaram os gêneros tradicionais que têm grande poder de se aproximar do leitor.

Um dos remédios é aquilo que ainda não vive, uma poesia que se aproveite dos novos recursos tecnológicos que estão ao seu alcance. O outro é o que já não vive mais, a poesia popular. Entre os dois, ele vai optar pelo que 
morreu. É desse mesmo momento a elaboração de Morte e vida severina, datada de 1954-1955, verdadeira concretização da opção de fazer poesia moderna a partir de formas tradicionais em desuso na poesia erudita. Assim, o arcabouço geral do poema, a escolha do auto de natal tradicional para dar conta de um novo movimento humano em direção aos centros urbanos, não é menos que a contraparte formal da verdadeira celebração da vida feita a partir da morte que constitui o poema. ${ }^{5}$

São da mesma época ainda, do livro Paisagens com figuras, também elaborado entre 1954 e 1955, os primeiros de uma série de poemas sobre cemitérios pernambucanos que João Cabral escreveria, nos quais o entrelaçamento entre vida e morte se fará de maneira exemplar em sua poesia. Mais tarde, em Quaderna, ele retornará ao tema, com dois novos cemitérios pernambucanos, um paraibano e um alagoano - além de um cemitério na cordilheira, em Agrestes e de toda a primeira parte, "Congresso no Polígono das Secas" de Dois parlamentos. Dois desses cemitérios pernambucanos me parecem bons para mostrar como a morte em Cabral ajuda a ver a vida:

\author{
Cemitério Pernambucano \\ (São Lourenço da Mata) \\ É cemitério marinho \\ mas marinho de outro mar. \\ Foi aberto para os mortos \\ que afoga o canavial.
}

As covas no chão parecem as ondas de qualquer mar, mesmo as de cana, lá fora, lambendo os muros de cal.

5 Vale a pena lembrar que a morte da música gerou em João Cabral uma nova música. Exemplo eloqüente são suas rimas toantes - eu preferiria chamar de meias-rimas -, que estão hoje incorparadas por outros por outros poetas e já representam um recurso formal corrente da poesia brasileira. Sem contar, é evidente, o efeito musical que têm na própria poesia de João Cabral, seja na sonoridade que elas próprias criam, seja na ênfase que, pelo contraste, dão a rimas perfeitas - e muitas vezes banais, em "ada", por exemplo - em alguns poemas: é como se fosse uma seqüência de sons dissonantes que se resolvessem num acorde perfeito que, nesse contexto, ganha uma beleza nova. 
Pois que os carneiros de terra parecem ondas de mar, não levam nomes: uma onda onde se viu batizar?

Também marinho: porque as caidas cruzes que há são menos cruzes que mastros quando a meio naufragar. ${ }^{6}$

Cemitério Pernambucano (Custódia)

É mais prático enterrar-se em covas feitas no chão: ao sol daqui mais que covas, são fornos de cremação.

Ao sol daqui, as covas logo se transformam nas caieiras onde enterrar certas coisas para, queimando-as, fazê-las:

assim, o tijolo ainda cru, as pedras que dão a cal ou a capoeira raquítica que dá o carvão vegetal.

Só que nas covas caieiras nenhuma coisa é apurada: tudo se perde na terra, em forma de alma, ou de nada. ${ }^{?}$

$\mathrm{Na}$ leitura conjunta chama a atenção, antes de mais nada, o corte feito no objeto descrito e o amplo panorama que esse corte deixa transparecer. Não

6 MELO NETO, p. 157. Poema originalmente publicado em Paisagens com figuras.

7 MELO NETO, p. 245-246. Poema publicado originalmente em Quaderna. 
é preciso recorrer a mapas para saber onde se localizam as cidades de São Lourenço da Mata e Custódia. É bem possível que esses cemitérios sejam muito parecidos, como são parecidos todos os cemitérios pobres: carneiros enfileirados e mal identificados. Mas não interessa simplesmente descrever os cemitérios. É preciso extrair daí o que está inscrito sobre a vida de quem é daquele lugar. Apenas por isso o cemitério de São Lourenço lembra o mar: os mortos ali enterrados são aqueles que trabalharam nos canaviais que, por sua vez, lembram o mar. Apenas por isso o cemitério de Custódia lembra as covas caieiras: porque ali vivem os sertanejos que fabricam o carvão e como ele se tostam no calor. Outro elemento central em ambos os poemas é o esvaziamento da morte. Num, as covas são como ondas, destituídas de identidade; noutro tudo se perde. Nada há para se olhar na morte, assim como nada há para se ver num cemitério. Mas muito se pode enxergar a partir de cemitérios: a vida.

O mesmo se pode dizer a respeito da morte de indivíduos. Nada há que se especular para além da morte. $O$ instante final serve só para iluminar o que veio antes. Assim é, por exemplo, o fim de um grande toureiro:

Por amor de moça mocinha que o recusara $\mathrm{e}$ às suas quintas,

mostrou que enfim era o mais forte: suicidou-se, mandou na morte,

ele que mandava nos touros com que ela sempre ameaçou-o,

de que escapava por um triz:

convocou-a, mas quando o quis. ${ }^{8}$

Ou de um grande poeta:

W. H. Auden

(1905-1973)

8 "Juan Belmonte". In: MELO NETO, p. 674. 
Se morre da morte que ela quer.

É ela que escolhe seu estilo, sem cogitar se a coisa que mata rima com sua morte ou faz sentido.

Mas ela certo te respeitava, de muito ler reler teus livros, pois matou-te com a guilhotina, fuzil limpo, do ataque cardíaco.

Aquele que desafiou a morte toda a vida impôs seus limites àquela que não conhece limites. Aquele que criou em vida, ganhou o respeito da morte, que o matou à maneira de sua própria obra. Assim como no cemitério o ofício daqueles que estão mortos define o aspecto do lugar onde estão enterrados, para os indivíduos em seu fim o ofício se impõe - o do toureiro, o do poeta assim como o da bailarina, o do pintor. O ofício é capaz de dominar os ritmos auto-suficientes da morte, de obter seu respeito e, da maneira que é possível, vencê-la. E vencê-la não é, como no célebre soneto de John Donne, ${ }^{10}$ matá-la pela via da permanência, da eternidade, mas sim por uma espécie de retorno esclarecedor à vida já vivida.

E a morte de João Cabral? Estaria ela inscrita já na sua obra, na sua vida? Teria havido também respeito por parte do inevitável? Quando ouvi dizer que o coração do poeta simplesmente parou e ele morreu sentado, ao rezar, tive a impressão de coisa absurda, de que só poderia ser mentira uma notícia dessas. Bastou, no entanto, lembrar-me de um poema importante para que mudasse de idéia:

9 MELO NETO, p. 382.

10 Falo aqui do décimo dos "Holly Sonnets": "Death be not proud, though some have called thee/ Mighty and dreadfull, for thou art not soc,/ For those, whom thou think'st, thou dost overthrow,/ Die not, poore death, nor yet canst thou kill me./ From rest and sleepe, which but thy pictures bee,/ Much pleasure, then from thee, much more must flow, / And soonest our best men with thee go,/ Rest bones, and soules deliverie./ Thou art slave to Fate, Chance, kings, and desperate men,/And dost with poyson, warre, and sickness dewll,/ And popie, or charmes can make us sleep as well,/ And better than thy stroake; why swell'st thou then?/ One short sleep past, wee wake eternaly, And death shall be no more: death, thou shalt die." DONNE, John. The complete poems and selected prose. New York: The Modern Library, [s.d], p. 250-251. 
BUENO, L. Morte que é vida

Autobiografia de um só dia

No engenho Poço não nasci:

minha mãe, na véspera de mim

veio de lá para a Jaqueira, que era onde, queiram ou não queiram,

os netos tinham de nascer, no quarto-avós, frente à maré.

Ou porque chegássemos tarde (não porque quisesse apressar-me,

e se soubesse o que teria de tédio à frente abortaria)

ou porque o doutor deu-me quandos, minha mãe no quarto-dos-santos,

misto de santuário e capela, lá dormiria, até que para ela

fizessem cedo no outro dia o quarto onde os netos nasciam.

Porém em pleno céu de gesso, naquela madrugada mesmo,

nascemos eu e minha morte, contra o ritual daquela Corte

que nada de um homem sabia: que ao nascer, esperneia, grita.

Parido no quarto-dos-santos, sem querer, nasci blasfemando, 
pois são blasfêmias sangue $\mathrm{e}$ grito

em meio à freirice de lírios,

mesmo se explodem (gritos, sangue), de chácara entre marés, mangues. ${ }^{11}$

A morte leu releu muito bem o poema do menino nascido junto com ela. Veio, como o nascimento, sem avisar, quando todos esperavam para um pouco mais tarde. Veio, como o nascimento, em meio à freirice, com a oração a substituir o ambiente do quarto-dos-santos. Ao contrário do nascimento, mas em perfeita simetria, como era de uso do poeta, veio em silêncio e não entre gritos, e um silêncio já longo do poeta, impossibilitado de escrever há alguns anos - o que não deixa de ser uma blasfêmia contra a vida como foram o grito e o sangue blasfêmia contra os santos.

Num tempo como o nosso, quando a vida parece valer tão pouco diante dos tais imperativos econômicos, a poesia de João Cabral continua ganhando um peso cada vez maior e, por trás da aparente frieza, um calor cada vez mais intenso. É uma força viva a atuar num meio literário em que triunfa um autor como Diogo Mainardi, cuja grande obsessão, além da auto-promoção, é gritar a verdade absoluta de que o homem não presta - e, a julgar por Polígono das Secas, os mais ignorantes prestam menos ainda. É bem verdade que o homem não é bom, mas no início do século que agora está no fim, é bom lembrar, o fascismo valeu-se desse princípio tão difícil de refutar - a crueldade da raça está inscrita no maior número das páginas da sua própria história - para afirmar que era preciso que alguns, os menos maus porque mais esclarecidos, subissem ao poder e controlassem a massa burra e má. Agora, quando se diz que as utopias não são mais possíveis, que o correto é ser pragmático e se proclama corajoso aquele que provoca o sofrimento do outro em nome de um duvidoso bem geral da nação, é preciso com urgência reafirmar a importância da vida de qualquer um. No edifício claro que João Cabral construiu pacientemente durante 50 anos há espaço suficiente para abrigá-la.

O Zé Carpina, bem no final de Morte e vida severina diz o seguinte:

é difícil defender,

só com palavras, a vida. ${ }^{12}$

11 MELO NETO, p. 439-440.

12 Ibid., p. 203. 
BUENO, L. Morte que é vida

As coisas fáceis nós mesmos fazemos. Mas as coisas difíceis, há também quem as faça. E um grande poeta como João Cabral pôde, só com palavras - no final das contas a única coisa que um poeta tem nas mãos - defender a vida.

\section{REFERÊNCIAS}

BANDEIRA, Manuel. Poesia completa e prosa. Rio de Janeiro: Nova Aguilar, 1990. DONNE, John. The complete poems and selected prose. New York: Modern Library, [s.d.].

MELO NETO, João Cabral de. Obras completas. Rio de Janeiro: Nova Aguilar, 1994. 